\title{
J2ME-Based 2D Rubber Puzzle Mobile Game
}

\author{
Waliya Rahmawanti ${ }^{* 1}$, Rogayah ${ }^{2}$, Nur Azizah $^{3}$ \\ ${ }^{1,2}$ Faculty of Computer Science and Information Technology, Gunadarma University \\ ${ }^{3}$ Fakultas Sains and Technology, University of Raharja \\ Email : ${ }^{* 1}$ waliya@staff.gunadarma.ac.id, ${ }^{2}$ rogayah@ staff.gunadarma.ac.id, \\ 3nur.azizah@raharja.info
}

\begin{abstract}
2D Rubix Game is part of an educational game. 2D Rubix Game in addition to being a medium of entertainment, is expected to help users sharpen their brains in managing strategy. $2 D$ rubix game has 4 levels, where the higher the level, the more difficult and many rubix dimensions. $2 D$ rubix game also has a new game menu, save, load game, and highscore. $2 D$ Rubix Game created using the Java programming language with J2ME functions. J2ME is a part of the Java programming language that can be used to create applications for various electronic media. Rubix 2D game has conducted a trial process on the emulator and all menus can run according to their functions
\end{abstract}

Keywords — Games, Education, Rubik, Java, J2ME.

\section{INTRODUCTION}

Mobile phones have very rapid technological developments. Cell phones are now heading towards multimedia. Cell phones initially had a function only as a communication tool, but nowadays cell phones are not only a communication tool but also have several features. These features are educational features such as campus search applications, learning support applications, and electronic dictionaries, in addition to educational features there are also entertainment features, such as games, music players, and video players. The networking features are also contained in features found on mobile phones, such as mini browsers, and social networking. The features contained in mobile phones, which are much interested in are social networking and entertainment features, namely games. Games are a feature that is in great demand by all circles, because the game is entertainment that makes it easy for someone to relieve stress and increase happiness in themselves. Games that have been widely developed use many $\mathrm{C}$ or $\mathrm{C} \#$ programs and also java programs ${ }^{[2]}$. Java has three editions with different functions, including:

a) Java 2 Standard Edition (J2SE) provides a feature-rich, stable, secure and crossplatform development environment. This edition supports database connectivity, user interface design, input / output, and network programming ${ }^{[3]}$.

b) Java 2 Enterprise Edition (J2EE) provides tools for building and running multitier enterprise applications. J2EE contains J2SE packages ${ }^{[3]}$.

c) Java 2 Micro Edition (J2ME) for a variety of consumer electronic products, such as pagers, smart cards, cell phones, handheld PDAs, and set-top boxes. J2ME excels in portability, capability to run anywhere and safe network delivery such as J2SE and J2EE ${ }^{[3]}$.

The reason the game is made by choosing the Java programming language is because of the advantages of Java itself, namely the portability in which java can be run on cell phones with different specifications while in the program using Java 2 MicroEdition (J2ME).

The game it has four levels and can only be played by one player. One player in this game means that the player can only play this game alone at the same time and cannot be played by several players (multiplayer) at one time. If other players want to play it must take 
turns with the previous player. Players will win if they succeed in arranging all colors in the same row or column and will be displayed on the High Score record. If the player gives up, he can repeat the game from the beginning by selecting new game or saving the game in progress by selecting the save menu and can play it again by selecting the load menu.

Writing is expected to make an interesting game application and can be played by various age groups, and can be used to train the brain in managing strategy. Because this game is designed to not only entertain but also to train intelligence in managing strategy.

\section{RESEARCH METHOD}

The research method used is to use the Software Development Life Cycle method. Software Development Life cycle is the stages of the work carried out by system analysts and programmers in building information systems. There are 6 stages in general in SDLC, namely: 1. Systems analysis, which is making an analysis of management workflows that are currently running. 2. Design System requirements specification, which is doing the details of what is needed in developing the system and making plans related to the system project. 3. System construction, i.e. making management workflow design and programming design needed for information systems development. 4. Implementation of the system, the stage of running the system in accordance with their respective functions. 5. System testing, i.e. testing the system that has been made. 6. Maintenance of the system, i.e. implementing and maintaining the system that has been created. ${ }^{[1]}$

Making 2D rubix games in the process of analyzing the problem by doing library research is the process of collecting data relating to the materials needed during making the application. Stages of data collection are done by searching literature both books and electronics via the internet. The data collected is a theory about mobile applications and the programming language that I use in this case is the Java programming language, especially J2ME.

The stages of application design, the authors divide it into two stages. The two stages are designing the interface that will be used and the process of designing a general description of the program to be made. The process of designing an interface consists of designing a menu structure, designing a layout. While the process of designing a general description of the program is done by making the program logic flow using a flowchart. The logic of this program illustrates the sequence of each step or procedure in the proper order.

The implementation phase of the application includes the hardware and software configuration used in making the application, the process of making the application, compiling and testing the application. At the application implementation stage, the process of coding or making the application is done at this stage.

The last stage in the project that the author did was the testing and compilation stages of the application. In this stage, the author tries to produce a standalone application with the *. Jar form to be installed on the mobile. But before that, the application can be run on an emulator integrated with Netbeans.

\section{RESULTS AND DISCUSSION}

This application is a mobile game application that can be played on mobile phones or devices that already support Java. This application has four forms which consist of the main menu display form, the level selection display, and the currently active game display. The menu display is a display that will allow users to do what they want. In the menu display there are menus for viewing game instructions (HELP / ABOUT), starting a new game (NEW GAME), saving a game (SAVE), playing a saved game (LOAD), seeing the highest value (HIGH SCORE), and for Exit the game (EXIT). Level selection display is a display that will force the user to choose the level to be played. The process will not continue if the user does 
not select the level you want to play. Active game display is a display that contains the game while it is playing. This form of display will adjust to the level that will be chosen by the user. Visualization of the navigation structure in outline can be seen in Figure 1 below.

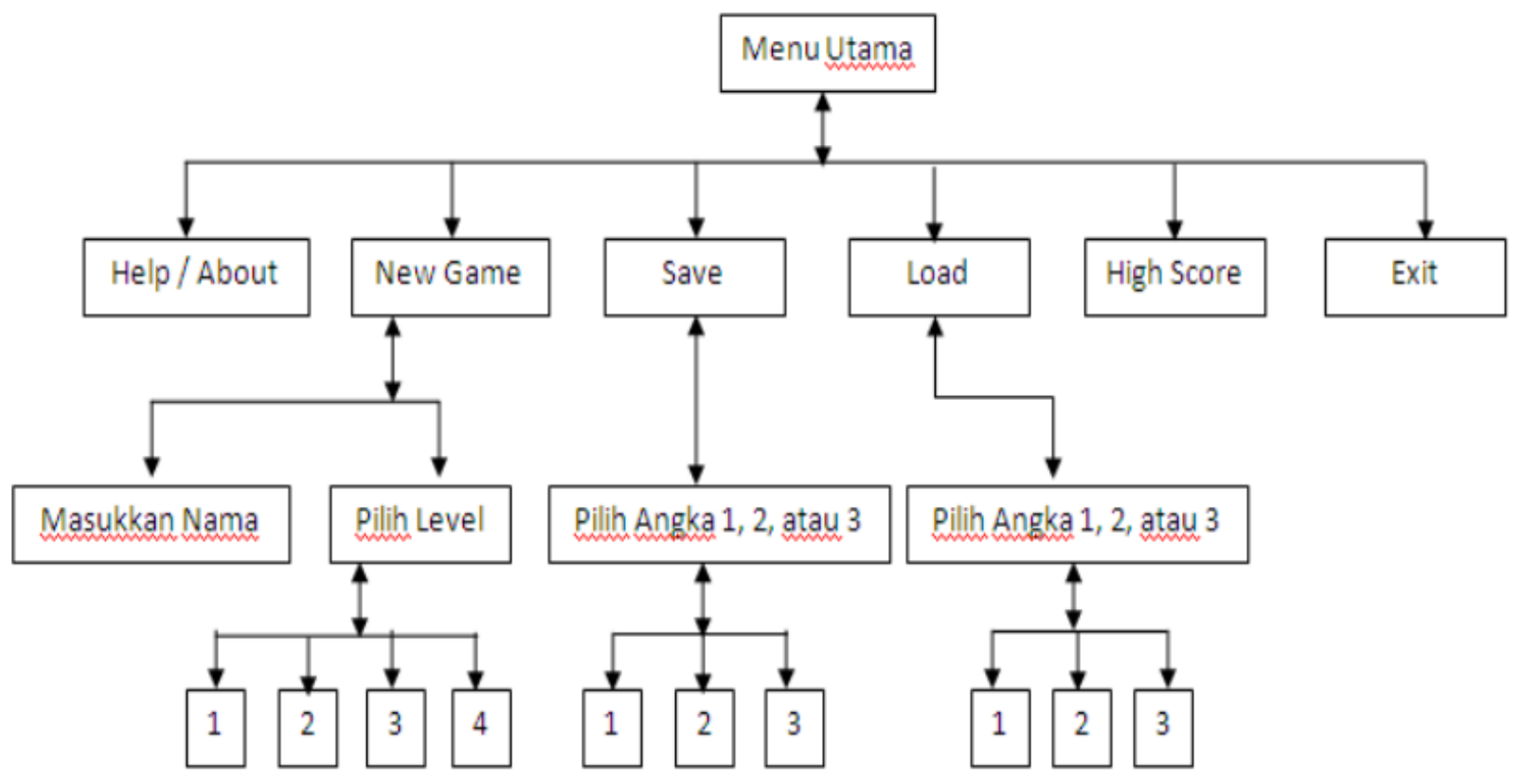

Figure 1. Navigation Structure of a 2D Rubix Game

Making 2D Rubix games in the design process is illustrated using a flowchart.Flowchart used is a program flowchart, because the program flowchart can provide more detailed information about how each step or procedure is in the right order. Flowchart to create a 2D rubix game application is as follows. 


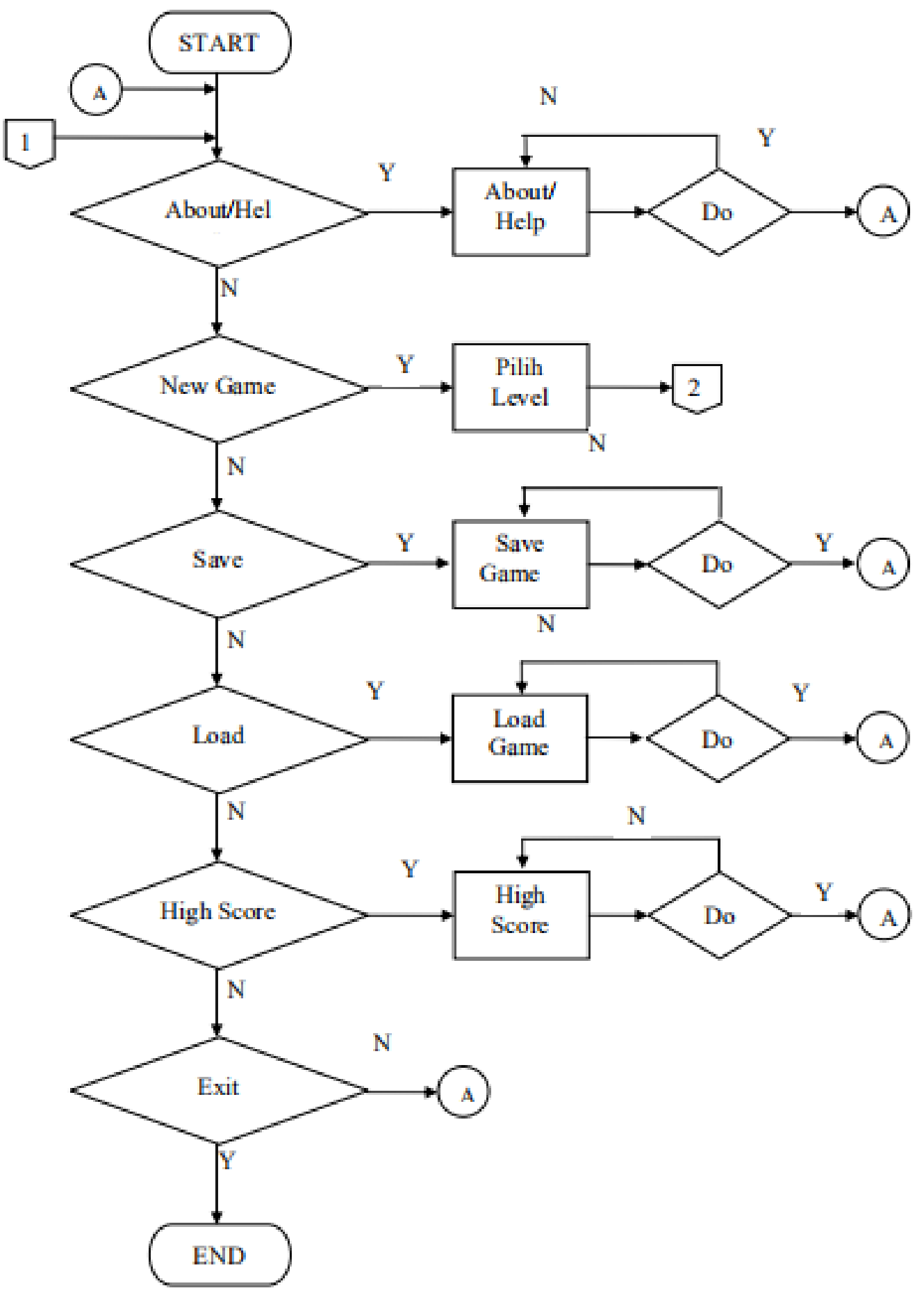

Figure 2. 2D Rubix Game Flow Chart 


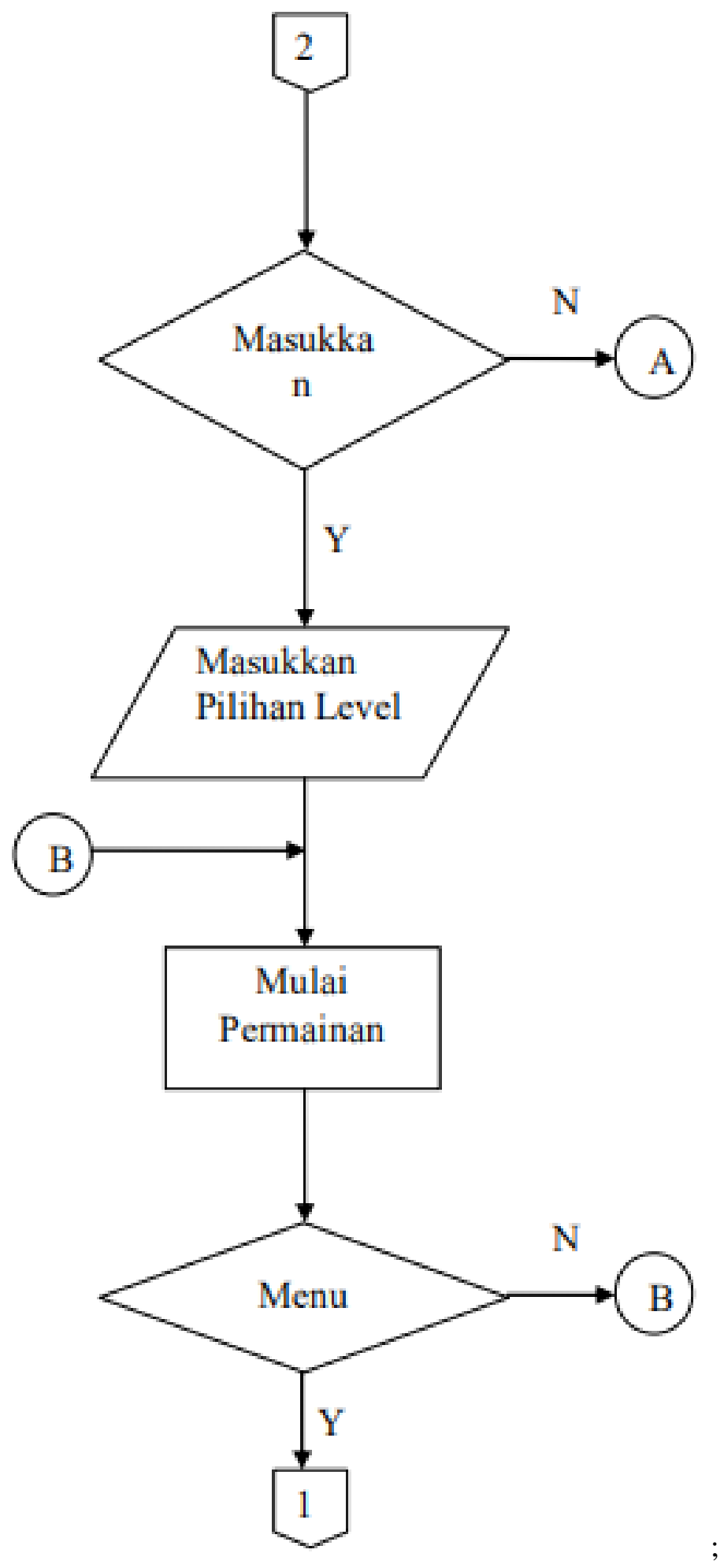

Figure 3. 2D Rubix Game Flow Chart (Continued)

After the flow chart is created, the application display design is made to facilitate the coding process. The application design created is the main menu, level, and active game. After the design the coding process is done, i.e. making the application by making it in accordance with the application design. Making an application using the java programming language with the function used is J2ME. 
Make the main view in the 2D rubix game using PNG format images, the images used are saved in the res folder. Res folder is a folder that is in the project folder that was created in the j2mewtk folder first. Images that have been saved will be displayed or used by using statements into one program block. The program block contains a class variable with a private type that makes variables that are in this class inaccessible to other classes, so that its nature will be exclusive to the class itself. In the statment program block that is used is a statment try that functions as a keyword to use a program block that must be protected from all exceptions. After completing the try block, use the catch statement to determine the type of exception that was captured.

The Help / About menu has a rubixredux statement package, the command indicates that the program block containing the statements for the help / about menu is stored in a class that can be organized in the rubixredux directory. The command is carried out to avoid naming conflicts and can facilitate the search for a particular class, because of the naming order based on the package created. Import the library contained in $\mathrm{j} 2 \mathrm{me}$ to display the string written into the program block by providing two quotation marks. The string contained in the program block is initialized into a class variable of type private, so that it can only be accessed by that class and the final modifier is added when declaring,

In the application display the player can choose the new game button, the player must choose the level of the game to be played. If the player has difficulty with the selected level, then the player can press the menu button to restart playing from the beginning. When the game is active, there is play time and the number of moves made by players on the moves chart. Games that have been played can be saved by pressing the save button. The game data is entered into a record with tyoe bytes. So the storage process will only enter one number for its naming and can be called back by pressing the game load button. The storage process is done when the last game was played. The game load button can be used to recall the previous game, The program block will call the record where the game is stored. The program block will redraw the canvas according to the position of the last saved game, so the player can continue the game as it was last played.

The highscore button is stored in the previously declared record / Highscore is stored based on the level chosen by the player, if the player chooses level 1 play, then the highest score obtained will be stored in the highscore at level 1 , as well as at other levels. Here's the look of the 2D Rubix Game: 

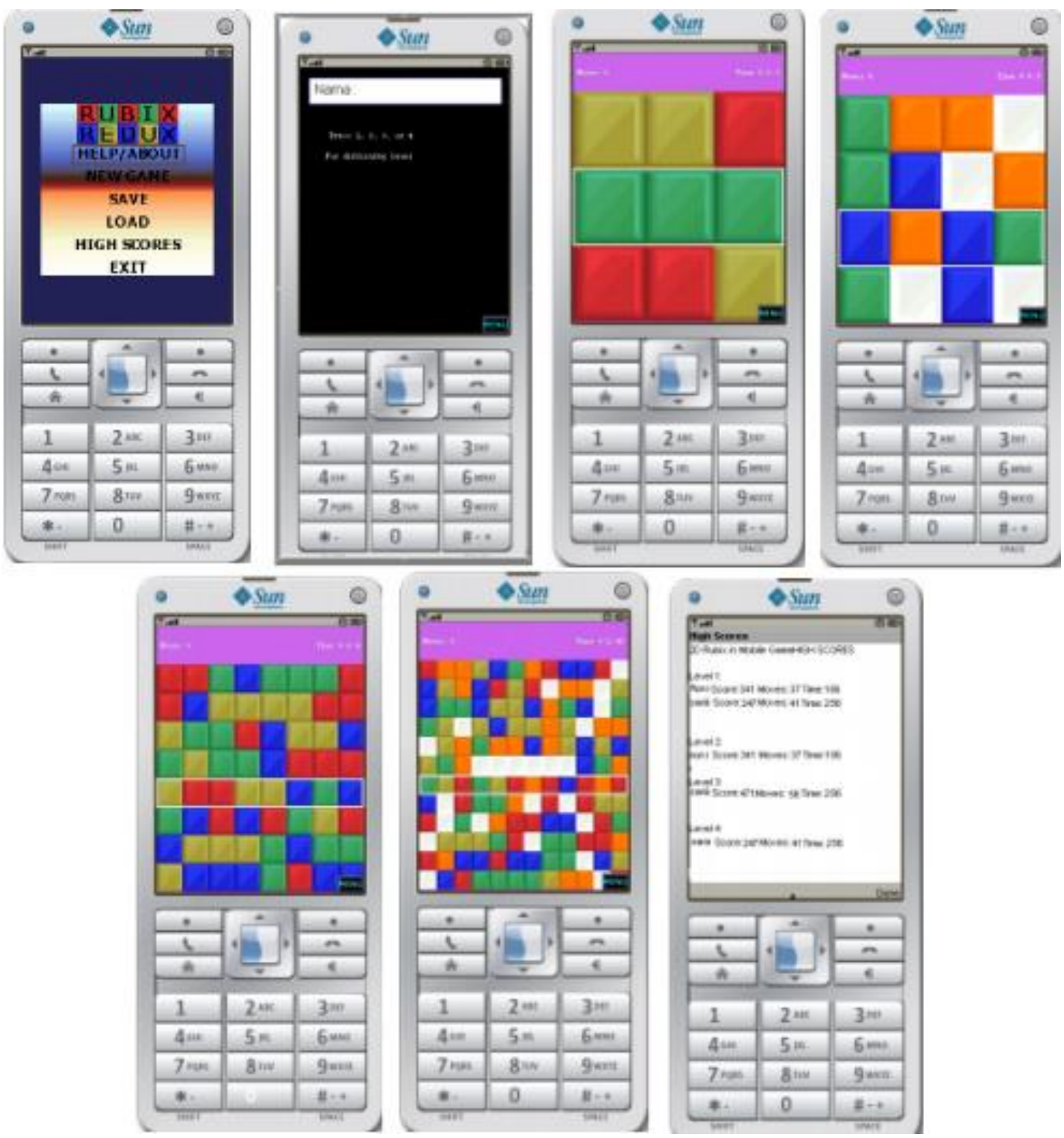

Figure 4. 2D Rubix Game Display

\section{CONCLUSION}

Rubix2D game has been successfully created using J2ME. 2D rubix games have tested the emulator. 2D rubix gamethis can be an alternative entertainment in leisure time, besides it can be used as a means to sharpen the brain and practice concentration for those who play it. $2 \mathrm{D}$ rubix games can train players to set the strategy for matching colors in the fastest way. $2 \mathrm{D}$ rubix games can still be developed, especially in terms of appearance that is only twodimensional, it would be even better if this application can be displayed in three dimensions so that it will be like the original rubix. Hopefully this rubix2D game application can be useful and will be better in its development later. 


\section{REFERENCES}

[1] Dwanoko, Yoyok Seby. 2016. "Implementation of Software Development Life Cycle (Sdlc) in Application of Software Application Development ". Journal of Information Technology. Vol 7. No.2

[2] Rahmat, Saleh \& Zulfandi. 2014. "J2ME Based Word Educational Game". Journal of Innovation. Vol. 01 No.1.2014.19-25.ISSN: 2355-701X.

[3] Brian, G. (2002). J2EE or J2SE? JNDI Works with Both, The Java Naming and Directory Interface is not just for J2EE applications. Java World. Accessed January 7, 2014. 